\title{
Corporate Governance And Firm Characteristics (The Sarbanes-Oxley Act Of 2002)
}

Annette Hebble, (Email: Hebble@stthomas.edu), University of St. Thomas Vinita Ramaswamy, (Email: VintaR@stthomas.edu), University of St. Thomas

\begin{abstract}
With the current attention focused on the Sarbanes-Oxley Act of 2002, it is timely to investigate the characteristics of firms that are early in implementing corporate governance policies pursuant to the Act. Since a relationship between corporate citizenship and financial success has been established in prior research, it is of interest to further probe these associations. The purpose of this particular study is to examine some characteristics of firms that were early in adopting corporate governance policies in response to the Act.
\end{abstract}

\section{INTRODUCTION}

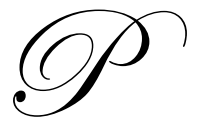

resident Bush signed The Sarbanes-Oxley Act of 2002 (SOX) on July 30, 2002. SOX is expected to have a significant, long-term impact on corporate governance and other related aspects such as disclosures, regulation of auditors, other auditor related services, SEC enforcement, securities litigation, compensation of officers and members of the board and financial analysts. SOX is already transforming lax governance practices in public companies. Public awareness of corporate governance matters is also heightened as a result of the law.

A major purpose of corporate governance is to protect the interests of shareholders. The concept of corporate governance is attracting a good deal of public interest not only because of SOX, but also because of mounting evidence of its importance for corporate financial success and general impact on society. However, the concept of corporate governance means different things to different people.

The Organization of Economic Cooperation and Development (OECD, April 1999) offers a general definition as follows: "Corporate governance is the system by which business corporations are directed and controlled. The corporate governance structure specifies the distribution of rights and responsibilities among different participants in the corporation, such as, the board, managers, shareholders and other stakeholders, and spells out the rules and procedures for making decisions on corporate affairs." Other definitions range from descriptive criteria such as the quality of the company's internal management to various types of proprietary governance rankings (for example The Corporate Library, Institutional Shareholder Services) by independent research and consulting organizations. It follows that the nature and success of attempts to link corporate governance and financial performance may depend to a certain extent on the definitions used.

\section{CORPORATE GOVERNANCE AND FIRM CHARACTERISTICS}

Numerous studies have investigated the relationship between corporate governance and financial success. Gompers et al. (2003) find that firms with strong shareholder rights have superior valuation, better profits, and better sales growth. Another study (Brown and Caylor, 2004) commissioned by Institutional Shareholder Services (ISS) has documented a relationship between size and corporate governance, and Claessens (2003) also demonstrates a relationship between corporate governance and improved performance. However, does superior corporate governance leads to improved financial performance or is it the other way around? The Claessens study shows that the 
relationship is not from better corporate governance to improved performance; rather it is either the other way around or because some other factors that drive both better corporate governance and better financial performance.

Belkaoui (2001) suggests that corporate audiences rate the performance of firms on the basis of the quality of their disclosures as well as market and accounting signals such as asset size, market returns and ROA. If companies are to reap the benefits of good corporate governance, they need to communicate such information to the various groups of stakeholders. The growing importance of corporate governance makes it important for companies to report on such activities in order to maximize shareholder values.

Since many definitions of corporate governance exist, it is of interest to further investigate some corporate characteristics of companies with and without corporate governance policies. Are complicated ranking criteria necessary to evaluate the relationship between corporate governance and financial performance? Maybe having a published policy available is enough of a signal to shareholders and stakeholders that the company takes corporate governance seriously. This study is exploratory in nature and probes relationships between a company's size, performance and risk characteristics with the existence of a published corporate governance policy. We are not making any qualitative judgments about corporate governance policies, but merely establishing whether a policy exists or not for each company.

\section{SAMPLE SELECTION}

The Corporate Library is an independent research firm that maintains corporate governance data for more than 2,000 U.S. companies. We searched the Corporate Library database and separated companies based on whether or not the company has a formal corporate governance policy in place.

The Corporate Library updates its listing on a quarterly basis and we compiled our listing based on information as of December 31, 2003. Compliance pursuant to the Sarbanes Oxley Act is required for many U.S. companies that file financial statements with the SEC after November 15, 2004. An exception exists for small and foreign companies that have until July 15, 2005 to comply. The data sample that we have represent a time period prior to the deadline, so we are able to differentiate between companies having adopted a formal corporate governance policy prior to the deadline for certification set forth by SOX. Adopting and publishing a corporate governance policy early can be an indication of the compliance efforts by companies.

It has previously been shown that size and corporate governance are related, so we group the companies by market valuation to gain further insights about firm characteristics and market capitalization. The sample is divided into large capitalization, mid-size and small capitalization categories. The distinction between large-mid -and small- caps are based on the following cut-offs. Large capitalization are companies that are worth in excess of five billion dollars, mid capitalization are those companies worth between one and five billion dollars. Small capitalization companies are worth between half a billion and one billion dollars.

For each size category, we collected a random sample of 40 companies. Further, the sample was split between companies with a corporate governance policy in place, and companies that do not have one. The total sample size is 120 companies out of a list of about 2,000 companies. These are all domestic companies but represent varied industries. No additional groupings of the data are made for this study.

\section{DATA ANALYSIS AND FINDINGS}

The financial data for our 120-company sample comes from Mergent Online. Specifically, we collected data relating to size, profitability and risk. The data is for the most current fiscal year for each company.

For size we look at assets, revenues, market cap, equity and employees. For profitability, we examine net income, net margin, return on assets (ROA) and return on equity (ROE). For the third category, risk we look at the debt to equity ratio, debt ratio, interest coverage and current ratio. We use t-tests to make the comparisons and the results are presented in Tables 1 through 4 at the end of this paper. Tables 5 and 6 show some additional descriptive 
statistics of firm characteristics form companies with and without a governance policy in place.

Our investigation of the full sample indicates that asset size is significant, i.e. there is a difference between the group of companies that already has a formal governance policy and those that do not. Market capitalization, total revenues and equity all show significant results. On the other hand, number of employees and total assets do not. The results for the-large-caps are consistent with the overall sample.

The mid- and small-cap groups show less consistent results. Total assets rather than market capitalization show significance. Equity is also inconsistent with the overall results. For the small-caps, total revenues and equity are the only two categories that appear to have some significance.

For profitability, net income, net profit margin and ROE are significant. Only ROA is not significant for the overall sample. This makes sense in that total asset category is not a significant factor. Again, the results vary somewhat within the groups. For large-caps, all profitability measures show some level of significance. Mid capitalization companies show significance for all categories except ROA, which is difficult to explain since total assets is significant for this category. For small capitalization companies only net profit margin and return of assets show significance.

The third measure risk indicates the most inconclusive results. Only interest coverage is significant in the overall sample as well as in all three-size categories.

\section{SUMMARY}

Overall, we do find that some measures of size and profitability show a correlation with having a formal corporate governance policy. This is an interesting finding in the wake of SOX with all its new compliance requirements.

Just like in a number of prior studies, a variation of the relationship between corporate governance and financial success is probed. The results are consistent with prior studies that show that some measures of asset size and profitability are correlated with corporate governance. It is not surprising that these relationships are again verified for public companies that are putting forth a serious effort with SOX compliance by adopting a corporate governance policy before the deadline for certification.

This information provides some interesting insights and provides ideas for refining the research in this area. Much investigation is still needed to probe the nature of the relationships and causality between corporate governance and corporate financial success.

Table 1

T-tests for All Companies (p-values)

\begin{tabular}{|c|c|c|c|c|c|}
\hline Size & Total Assets & Total Revenues & Market Cap. & St. Equity & Employees \\
\hline & 0.16 & 0.02 & 0.04 & 0.03 & 0.16 \\
\hline Profitability & Net Income & Net Profit Margin & ROA & ROE & \\
\hline & 0.01 & 0.06 & 0.54 & 0.02 & \\
\hline Risk & Debt/Equity & Debt Ratio & Interest Coverage & Current Ratio & \\
\hline & 0.57 & 0.42 & 0.09 & 0.12 & \\
\hline
\end{tabular}

Table 2

T-test for Large Caps (> 5 billions)

\begin{tabular}{|l|c|c|c|c|c|}
\hline \multicolumn{1}{|c|}{ Size } & Total Assets & Total Revenues & Market Cap. & St. Equity & Employees \\
\hline & 0.20 & 0.08 & 0.01 & 0.05 & 0.24 \\
\hline Profitability & Net Income & Net Profit Margin & ROA & ROE & \\
\hline & 0.06 & 0.02 & 0.04 & 0.10 & \\
\hline Risk & Debt/Equity & Debt Ratio & Interest Coverage & Current Ratio & \\
\hline & 0.38 & 0.13 & 0.01 & 0.24 & \\
\hline
\end{tabular}


Table 3

T-test for Mid Caps ( 1 - 5 billions)

\begin{tabular}{|l|l|l|l|l|l|}
\hline \multicolumn{1}{|c|}{ Size } & \multicolumn{1}{|c|}{ Total Assets } & \multicolumn{1}{|c|}{ Total Revenues } & \multicolumn{1}{c|}{ Market Cap. } & \multicolumn{1}{c|}{ St. Equity } & Employees \\
\hline & 0.01 & 0.08 & 0.64 & 0.32 & 0.22 \\
\hline Profitability & Net Income & Net Profit Margin & ROA & ROE & \\
\hline & 0.00 & 0.06 & 0.18 & 0.01 & \\
\hline Risk & Debt/Equity & Debt Ratio & Interest Coverage & Current Ratio & \\
\hline & 0.43 & 0.03 & 0.04 & 0.02 & \\
\hline
\end{tabular}

Table 4

T-test for Small Caps (.5 - 1 billion)

\begin{tabular}{|l|c|c|c|c|c|}
\hline \multicolumn{1}{|c|}{ Size } & Total Assets & Total Revenues & Market Cap. & St. Equity & Employees \\
\hline & 0.65 & 00.02 & 0.65 & 0.03 & 0.31 \\
\hline Profitability & Net Income & Net Profit Margin & ROA & ROE & \\
\hline & 0.52 & 0.03 & 0.05 & 0.42 & \\
\hline Risk & Debt/Equity & Debt Ratio & Interest Coverage & Current Ratio & \\
\hline & 0.40 & 0.18 & 0.05 & 0.41 & \\
\hline
\end{tabular}

Table 5

Descriptive Characteristics - All Companies without Governance Policies

\begin{tabular}{|l|c|c|c|c|c|}
\hline & Maximum & Minimum & Average & Median & Std. Dev \\
\hline Total Assets (in '000's) & $254,320,000$ & 213,100 & $24,478,000$ & $2,836,018$ & $101,441,010$ \\
Total Revenues (in '000's) & $41,444,000$ & 12,872 & $4,866,079$ & $1,215,966$ & $9,058,687$ \\
Market Cap. (in '000's) & $42,675,000$ & 532,000 & $4,490,000$ & $1,875,000$ & $11,742,000$ \\
Stockholder's Equity (in '000's) & $31,330,000$ & $-363,177$ & $3,049,765$ & 738,859 & $6,021,507$ \\
No. of Employees & 246,000 & 55 & 15,639 & 5,274 & 35,032 \\
Net Income (in '000's) & $10,090,000$ & $-1,433,000$ & 235,998 & 50,600 & $1,471,062$ \\
Net Profit Margin & 57.13 & -1757.42 & -18.85 & 11.20 & 231.76 \\
ROA & 18.37 & -43.68 & 2.93 & 3.44 & 8.83 \\
ROE & 42.12 & -398.34 & -1.72 & 10.21 & 64.80 \\
Debt/Total Assets & 0.63 & 0.00 & 0.23 & 0.17 & 0.20 \\
Debt/Equity & 8.71 & 0.77 & 2.28 & 1.60 & 1.54 \\
Interest Coverage & $11,530.5$ & -17.09 & 357.61 & 3.11 & 1890.41 \\
Current Ratio & 284.48 & 0.02 & 6.82 & 1.74 & 36.80 \\
\hline
\end{tabular}

Table 6

Descriptive Characteristics - All Companies with Governance Policies

\begin{tabular}{|l|c|c|c|c|c|}
\hline & Maximum & Minimum & Average & Median & Std. Dev \\
\hline Total Assets (in '000's) & $752,249,000$ & 288,008 & $14,354,300$ & $3,449,482$ & $38,753,835$ \\
Total Revenues (in '000's) & $120,732,000$ & $114,786,000$ & $7,362,861$ & $2,591,408$ & $17,121,155$ \\
Market Cap. (in '000's) & $87,003,000$ & 544,000 & $6,540,559$ & $1,963,000$ & $13,971,717$ \\
Stockholder's Equity (in '000's) & $63,205,000$ & 146,124 & $4,450,449$ & 897,527 & $10,219,576$ \\
No. of Employees & 143,000 & 28 & 20,071 & 7,031 & 29,790 \\
Net Income (in '000's) & $7,230,000$ & $-323,260$ & 584,930 & 81,620 & $1,449,442$ \\
Net Profit Margin & 54.2 & -198.78 & 8.97 & 11.78 & 31.37 \\
ROA & 16.02 & -46.75 & 3.28 & 4.62 & 9.58 \\
ROE & 40.28 & -114.46 & 9.32 & 12.86 & 21.99 \\
Debt/Total Assets & 0.67 & 0.00 & 0.22 & 0.19 & 0.16 \\
Debt/Equity & 15.71 & 1.08 & 2.17 & 1.77 & 1.94 \\
Interest Coverage & 708.19 & -54.45 & 25.04 & 8.43 & 103.46 \\
Current Ratio & 12.90 & 0.03 & 2.00 & 1.38 & 1.98 \\
\hline
\end{tabular}




\section{REFERENCES}

1. Belkaoui, A., "The Extent of Environmental Disclosures: Effects of Regulatory Costs and Level of Exposure to Environmental Risk", International Journal of Environmental Technology and Management, Vol. 1, No., $1 / 2,2001$.

2. Brown, L., Caylor, M., Brown, "Corporate Governance Study Links Bad Boards to Higher Risks and Increased Volatility", A Study Commissioned by ISS, February 4, 2004.

<http://www.issproxy.com/pdf/Correlation_study_020304.pdf>

3. Claessens, S. Corporate, "Governance and Development, Global Corporate Governance Forum", The International Bank for Reconstruction and Development/The World Bank, 2003.

http://scholar.google.com/scholar?hl=en\&lr=\&q=cache:JSa7gDGNUnQJ:www.gcgf.org/library/Discussion

4. _Papers_and_Focus\%2520Notes/Focus_1_Corp_Governance_and_Development.pdf+Claessens+Governanc e+Developmentk, The Corporate Library, 2004. < http://www.thecorporatelibrary.com>

5. Encycogov.com, "The Encyclopedia About Corporate Governance", December 10, 2004.

<http://www.encycogov.com/WhatIsGorpGov.asp>

6. Gompers, P, Ishii, J., Metrick, A., “Corporate Governance and Equity Prices”, The Quarterly Journal of Economics, February 2003. Institutional Shareholder Services, 2004. <http://www.issproxy.com/index.jsp>

7. Mergent Online. 2003. Library, University of St. Thomas, Houston, TX, September 2004. <http://www.mergentonline.com/compsearch.asp>

8. "Sarbanes-Oxley Act of 2002", Public Law 107-204, 107 Congress, July 30, 2002.

\section{NOTES}


NOTES 